\title{
Modeling the impact of heterogeneous reactions of chlorine on summertime nitrate formation in Beijing, China
}

\author{
Xionghui Qiu ${ }^{1,2}$, Qi Ying ${ }^{3}$, Shuxiao Wang ${ }^{1,2}$, Lei Duan ${ }^{1,2}$, Jian Zhao ${ }^{4}$, Jia Xing ${ }^{1,2}$, Dian Ding ${ }^{1,2}$, Yele Sun ${ }^{4}$, \\ Baoxian $\mathrm{Liu}^{5}$, Aijun Shi ${ }^{6}$, Xiao Yan $^{6}$, Qingcheng $\mathrm{Xu}^{1,2}$, and Jiming Hao ${ }^{1,2}$ \\ ${ }^{1}$ State Key Joint Laboratory of Environmental Simulation and Pollution Control, School of Environment, \\ Tsinghua University, Beijing 100084, China \\ ${ }^{2}$ State Environmental Protection Key Laboratory of Sources and Control of Air Pollution Complex, \\ School of Environment, Tsinghua University, Beijing 100084, China \\ ${ }^{3}$ Zachry Department of Civil Engineering, Texas A\&M University, College Station, Texas 77843-3138, USA \\ ${ }^{4}$ State Key Laboratory of Atmospheric Boundary Layer Physics and Atmospheric Chemistry, \\ Institute of Atmospheric Physics, Chinese Academy of Sciences, Beijing 100029, China \\ ${ }^{5}$ Beijing Environmental Monitoring Center, Beijing 100048, China \\ ${ }^{6}$ Beijing Municipal Research Institute of Environmental Protection, Beijing 100037, China
}

Correspondence: Qi Ying (qying@civil.tamu.edu) and Shuxiao Wang (shxwang@tsinghua.edu.cn)

Received: 6 December 2018 - Discussion started: 20 December 2018

Revised: 9 May 2019 - Accepted: 10 May 2019 - Published: 21 May 2019

\begin{abstract}
Comprehensive chlorine heterogeneous chemistry is incorporated into the Community Multiscale Air Quality (CMAQ) model to evaluate the impact of chlorinerelated heterogeneous reaction on diurnal and nocturnal nitrate formation and quantify the nitrate formation from gasto-particle partitioning of $\mathrm{HNO}_{3}$ and from different heterogeneous pathways. The results show that these heterogeneous reactions increase the atmospheric $\mathrm{Cl}_{2}$ and $\mathrm{ClNO}_{2}$ level $(\sim 100 \%)$, which further affects the nitrate formation. Sensitivity analyses of uptake coefficients show that the empirical uptake coefficient for the $\mathrm{O}_{3}$ heterogeneous reaction with chlorinated particles may lead to the large uncertainties in the predicted $\mathrm{Cl}_{2}$ and nitrate concentrations. The $\mathrm{N}_{2} \mathrm{O}_{5}$ uptake coefficient with particulate $\mathrm{Cl}^{-}$concentration dependence performs better in capturing the concentration of $\mathrm{ClNO}_{2}$ and nocturnal nitrate concentration. The reaction of $\mathrm{OH}$ and $\mathrm{NO}_{2}$ in the daytime increases the nitrate by $\sim 15 \%$ when the heterogeneous chlorine chemistry is incorporated, resulting in more nitrate formation from $\mathrm{HNO}_{3}$ gas-to-particle partitioning. By contrast, the contribution of the heterogeneous reaction of $\mathrm{N}_{2} \mathrm{O}_{5}$ to nitrate concentrations decreases by about $27 \%$ in the nighttime, when its reactions with chlorinated particles are considered. However, the generated gas-phase $\mathrm{ClNO}_{2}$ from the heterogeneous reaction of
\end{abstract}

$\mathrm{N}_{2} \mathrm{O}_{5}$ and chlorine-containing particles further reacts with the particle surface to increase the nitrate by $6 \%$. In general, this study highlights the potential of significant underestimation of daytime concentrations and overestimation of nighttime nitrate concentrations for chemical transport models without proper chlorine chemistry in the gas and particle phases.

\section{Introduction}

In recent years, nitrate has become the primary component of $\mathrm{PM}_{2.5}$ (particulate matter with an aerodynamic diameter less than $2.5 \mu \mathrm{m}$ ) in Beijing, with sustained and rapid reduction of $\mathrm{SO}_{2}$ and primary particulate matter emissions (Ma et al., 2018; Li et al., 2018; Wen et al., 2018). Observations showed that the relative contributions of secondary nitrate in $\mathrm{PM}_{2.5}$ could reach up to approximately $50 \%$ during some severe haze pollution days (Li et al., 2018). The mechanism of secondary nitrate formation can be summarized as two major pathways. (1) Gas-to-particle partitioning of $\mathrm{HNO}_{3}$ happens mostly in the daytime. The reaction of $\mathrm{OH}$ with $\mathrm{NO}_{2}$ produces gaseous $\mathrm{HNO}_{3}$, which subsequently partitions into the particle phase. The existence of $\mathrm{NH}_{3}$ or basic parti- 
cles enhances this process by $\mathrm{NH}_{3}-\mathrm{NH}_{4}^{+}$gas-particle equilibrium (Kleeman et al., 2005; Seinfeld and Pandis, 2006). (2) Hydrolysis of $\mathrm{N}_{2} \mathrm{O}_{5}$ is more important during the nighttime, when $\mathrm{N}_{2} \mathrm{O}_{5}$ forms from the reactions of $\mathrm{NO}_{2}, \mathrm{O}_{3}$ and $\mathrm{NO}_{3}$ and hydrolyzes to produce particulate nitrate. They can be summarized as Reactions (R1)-(R5) (Brown and Stutz, 2012):

$$
\begin{aligned}
& \mathrm{OH}+\mathrm{NO}_{2} \rightarrow \mathrm{HNO}_{3}, \\
& \mathrm{HNO}_{3}+\mathrm{NH}_{3} \rightarrow \mathrm{NH}_{4}^{+}+\mathrm{NO}_{3}^{-}, \\
& \mathrm{NO}_{2}+\mathrm{O}_{3} \rightarrow \mathrm{NO}_{3}+\mathrm{O}_{2}, \\
& \mathrm{NO}_{3}+\mathrm{NO}_{2} \leftrightarrow \mathrm{N}_{2} \mathrm{O}_{5}, \\
& \mathrm{~N}_{2} \mathrm{O}_{5}+\mathrm{H}_{2} \mathrm{O}(\mathrm{aq}) \rightarrow 2 \mathrm{H}^{+}+2 \mathrm{NO}_{3}^{-} .
\end{aligned}
$$

In addition to Reactions (R1) and (R5), gas-phase reactions of $\mathrm{NO}_{3}$ with $\mathrm{HO}_{2}$ and VOCs, $\mathrm{N}_{2} \mathrm{O}_{5}$ with water vapor (Tuazon et al., 1983), and the heterogeneous reaction of $\mathrm{NO}_{2}$ with the water-containing particle (Goodman et al., 1999) produce $\mathrm{HNO}_{3}$ or nitrate as well. Theses reactions are listed in Table 2 as Reactions (R8), (R9) and (R10).

However, chemistry transport models (CTMs) incorporated with these mechanisms still cannot accurately capture the spatiotemporal distributions of nitrate in some studies in polluted northern China. For example, Chang et al. (2018) showed that the simulated nitrate concentrations derived from the default Community Multiscale Air Quality (CMAQ; version 5.0.2) were significantly higher than the observations in summer at two sites adjacent to Beijing. Fu et al. (2016) also found that the default CMAQ (version 5.0.1) overestimated the simulated nitrate concentrations in the BeijingTianjin-Hebei region.

In recent fields studies, it was found that high particulate chlorine emissions might have a significant impact on the oxidation capacity of the urban atmosphere and thus could affect nitrate concentrations. According to the field measurements in June 2017 in Beijing (Zhou et al., 2018), the $2 \mathrm{~min}$ averaged concentrations of reactive molecular chlorine $\left(\mathrm{Cl}_{2}\right)$ and nitryl chloride $\left(\mathrm{ClNO}_{2}\right)$ reached up to 1000 and 1200 pptv, respectively, during some severe air pollution periods in summer. The $\mathrm{Cl}_{2}$ concentrations were significantly higher than those observed in North American coastal cities affected by onshore flow and the lower atmosphere in the remote Arctic region (Spicer et al., 1998; Glasow, 2010; Liu et al., 2017). During these pollution events, the corresponding concentrations of $\mathrm{N}_{2} \mathrm{O}_{5}$ ( 2 min average) and nitrate (5 min average) rose from $40 \mathrm{pptv}$ and $1 \mu \mathrm{g} \mathrm{m}^{-3}$ to $700 \mathrm{pptv}$ and $5 \mu \mathrm{g} \mathrm{m}^{-3}$. To explain the high levels of $\mathrm{ClNO}_{2}$, some studies suggested that Reaction (R5) should be revised to account for $\mathrm{ClNO}_{2}$ production from the heterogeneous reaction of $\mathrm{N}_{2} \mathrm{O}_{5}$ on chloride-containing particles (CPs; Osthoff et al., 2008; Thornton et al., 2010), as shown in Reaction (R6):

$$
\begin{aligned}
& \mathrm{N}_{2} \mathrm{O}_{5}+(1-\phi) \mathrm{H}_{2} \mathrm{O}+\phi \mathrm{Cl}^{-} \rightarrow \phi \mathrm{ClNO}_{2} \\
& +(2-\phi) \mathrm{NO}_{3}^{-},
\end{aligned}
$$

where $\phi$ represents the molar yield of $\mathrm{ClNO}_{2}$. By incorporating this reaction into WRF-Chem, Li et al. (2016) found that the improved model performed better in matching the observed nitrate concentrations in Hong Kong during 15 November and 5 December 2013. However, $\mathrm{ClNO}_{2}$ could affect the formation of nitrate indirectly by increasing the atmospheric $\mathrm{OH}$ after a series of chemical reactions, which are briefly summarized into three steps: (1) the photolysis of $\mathrm{ClNO}_{2}$ produces chlorine radicals $\left(\mathrm{Cl}^{\circ}\right),(2)$ the reaction of $\mathrm{Cl}^{\bullet}$ with VOCs produces the peroxy radical $\left(\mathrm{HO}_{2}\right.$ and $\left.\mathrm{RO}_{2}\right)$, and (3) the increased $\mathrm{HO}_{2}$ and $\mathrm{RO}_{2}$ prompt the formation of $\mathrm{OH}$ through the $\mathrm{HO}_{x}$ cycle and lead to increased $\mathrm{HNO}_{3}$ production (Young et al., 2014; Jobson et al., 1994). The overall impact of Reaction (R6) on nitrate remains to be investigated.

Another related but unresolved issue is the sources of the high concentrations of $\mathrm{Cl}_{2}$, which could not be explained by the $\mathrm{N}_{2} \mathrm{O}_{5}$ heterogeneous reaction with $\mathrm{Cl}^{-}$and the subsequent reactions of $\mathrm{ClNO}_{2}$ in the gas phase. It has been reported that the reactions of gaseous $\mathrm{O}_{3}, \mathrm{OH}, \mathrm{HO}_{2}, \mathrm{ClNO}_{2}$, hypochlorous acid $(\mathrm{HOCl})$ and chlorine nitrate $\left(\mathrm{ClONO}_{2}\right)$ with $\mathrm{CPs}$ can produce $\mathrm{Cl}_{2}$, which can subsequently photolyze to produce $\mathrm{Cl}^{-}$(Knipping et al., 2000; George and Abbatt, 2010; Pratte and Rossi, 2006; Deiber et al., 2004; Faxon et al., 2015). However, these heterogeneous reactions in CPs are generally missing in most of the current CTMs, and it is unclear whether these reactions will be able to explain the observed $\mathrm{Cl}_{2}$ concentrations and the overall impact of these reactions on nitrate.

Previously, biomass burning, coal combustion and waste incineration were identified as the main sources of gaseous and particulate chlorine compounds in China from the International Global Atmospheric Chemistry program's Global Emissions Inventory Activity (GEIA) based on the year 1990 and a localized study by Fu et al. (2018) based on the year 2014 (Keene et al., 1999; Fu et al., 2018). However, recent source apportionment results of $\mathrm{PM}_{2.5}$ in Beijing showed that the contribution of coal combustion had extremely decreased from $22.4 \%$ in 2014 to $3 \%$ in 2017 with the replacement of natural gas (obtained from official website of the Beijing Municipal Bureau of Statistics, available at http://edu.bjstats. gov.cn/, last access: 5 May 2018). Another important source - cooking - has received attention with its increasing contribution to $\mathrm{PM}_{2.5}$ (accounting for $33 \%$ of the residential sector; obtained from the official source apportionment analysis of $\mathrm{PM}_{2.5}$ in Beijing in 2017; see http://sthjj.beijing.gov.cn/, last access: 5 May 2018). Moreover, the high content of particulate sodium chloride was measured from the source characterization studies of $\mathrm{PM}_{2.5}$ released from the cooking activities (Zhang et al., 2016). Thus, it is necessary to compile an updated emission inventory for Beijing to include the emissions from cooking and other sources (coal burning, solid waste incineration, biomass burning, etc.) in order to explore the emissions of the chlorine species on atmospheric nitrate formation. 
In this study, a CMAQ model with improved chlorine heterogeneous chemistry is applied to simulate summer nitrate concentration in Beijing. Sensitivity simulations are conducted to evaluate the contributions of $\mathrm{HNO}_{3}$ gas-to-particle partitioning and heterogonous production to aerosol nitrate. The results of this work can improve our understandings on nitrate formation and provide useful information on nitrate pollution control strategies in Beijing.

\section{Emissions, chemical reactions and model description}

\subsection{Emissions}

Generally, the conventional emission inventories of air pollutants in China only include the common chemical species, such as $\mathrm{SO}_{2}, \mathrm{NO}_{x}, \mathrm{VOCs}, \mathrm{PM}_{2.5}, \mathrm{PM}_{10}, \mathrm{NH}_{3}, \mathrm{BC}$ and $\mathrm{OC}$ (Wang et al., 2014). Chloride compound emissions were not included. However, the emissions of chlorine species are vital for studying the chlorine chemical mechanism. Recently, the inorganic hydrogen chloride $(\mathrm{HCl})$ and fine particulate chloride $(\mathrm{PCl})$ emission inventories for the sectors of coal combustion, biomass burning and waste incineration were developed for the year 2014 (Qiu et al., 2016; Fu et al., 2018; Liu et al., 2018). However, gaseous chlorine emissions were not estimated in these studies. In addition, these studies did not account for the rapid decrease in coal consumption in recent years in Beijing, from $2000 \mathrm{Mt}$ in 2014 to $490 \mathrm{Mt}$ in 2017. More importantly, the cooking source, as one of the major contributors to particulate chlorine in Beijing, is not included in current chlorine emission inventories. Thus, a new emission inventory of reactive chlorine species, which includes $\mathrm{HCl}, \mathrm{Cl}_{2}$ and $\mathrm{PCl}$, was developed in this study for the year 2017.

The emission factor method (Eq. 1) is applied to calculate the emissions of these reactive chlorine species from coal combustion, biomass burning, municipal solid waste incineration and industrial processes:

$E_{i, j}=A_{i} \times \mathrm{EF}_{i, j}$

where $E_{i, j}$ represents the emission factor of pollutant $j$ in sector $i, A$ represents the activity data and EF represents the emission factor. The $\mathrm{EF}$ for $\mathrm{PCl}$ is estimated by $\mathrm{EF}_{i, \mathrm{PCl}}=\mathrm{EF}_{i, \mathrm{PM}_{2.5}} \times f_{\mathrm{Cl}, i}$, where $f_{\mathrm{Cl}, i}$ represents the mass fraction of $\mathrm{PCl}$ in primary $\mathrm{PM}_{2.5}$. Activity data are obtained from the Beijing Municipal Bureau of Statistics (available at http://tjj.beijing.gov.cn/, last access: 4 May 2018). The $\mathrm{Cl}_{2}$ emission factor for coal combustion is calculated based on the content of $\mathrm{Cl}$ in coal, which was measured by Deng et al. (2014). The $\mathrm{PM}_{2.5}$ emission factors and mass fractions of $\mathrm{PCl}$ in $\mathrm{PM}_{2.5}$ to calculate the emissions of $\mathrm{Cl}$ were described in detail by Fu et al. (2018). $\mathrm{PCl}$ in $\mathrm{PM}_{2.5}$ for coal combustion and biomass burning is taken as $1 \%$ and $9.0 \%$, respectively, based on local measurements in Beijing.
Table 1. The sectoral emissions of $\mathrm{HCl}, \mathrm{Cl}_{2}$ and $\mathrm{PCl}$ in Beijing in 2017 (unit: $\mathrm{Mg} \mathrm{yr}^{-1}$ ).

\begin{tabular}{lrrr}
\hline \multirow{2}{*}{ Sector } & \multicolumn{3}{c}{ Emissions } \\
\cline { 2 - 4 } & $\mathrm{HCl}$ & $\mathrm{Cl}_{2}$ & $\mathrm{PCl}$ \\
\hline Power plant & 22.8 & 1.2 & 6.75 \\
Industry & 587.3 & 20.1 & 89.2 \\
Residential & 202.4 & 8.1 & 34.7 \\
Biomass burning & 0.182 & 0 & 0.14 \\
Municipal solid waste & 1080.2 & 0 & 8.47 \\
Cooking & 0 & 0 & 426.8 \\
Total & 1892.9 & 29.4 & 566.1 \\
\hline
\end{tabular}

Emissions of $\mathrm{PCl}$ from cooking, including contributions from commercial and household cooking, are estimated using Eq. (2):

$$
\begin{aligned}
E_{\mathrm{PCl}}= & {\left[N_{\mathrm{f}} \times V_{\mathrm{f}} \times H_{\mathrm{f}} \times \mathrm{EF}_{\mathrm{f}, \mathrm{PCl}}+V_{\mathrm{c}} \times H_{\mathrm{c}} \times N_{\mathrm{c}}\right.} \\
& \left.\times n \times \mathrm{EF}_{\mathrm{c}, \mathrm{PCl}} \times(1-\eta)\right] \times 365,
\end{aligned}
$$

where $N_{\mathrm{f}}$ is the number of households; $V_{\mathrm{f}}$ is the volume of exhaust gas from a household stove $\left(2000 \mathrm{~m}^{3} \mathrm{~h}^{-1}\right) ; H_{\mathrm{f}}$ is the cooking time for a family $\left(0.5 \mathrm{~h} \mathrm{~d}^{-1}\right) ; \mathrm{EF}_{\mathrm{f}, \mathrm{PCl}}$ and $\mathrm{EF}_{\mathrm{c}, \mathrm{PCl}}$ are the emission factors $\left(\mathrm{kg} \mathrm{m}^{-3}\right)$ of $\mathrm{PCl}$ for household and commercial cooking, respectively; $H_{\mathrm{c}}$ is the cooking time in a commercial cooking facility $\left(6 \mathrm{~h} \mathrm{~d}^{-1}\right) ; N_{\mathrm{c}}$ is the number of restaurants, schools and government departments; $V_{\mathrm{c}}$ is the volume of exhaust gas from a commercial cooking stove $\left(8000 \mathrm{~m}^{3} \mathrm{~h}^{-1}\right)$; and $n$ is the number of stoves for each unit, which is six for a restaurant and is calculated as one stove per 150 students for each school. $\eta$ is the removal efficiency of fume scrubbers $(30 \%) . \mathrm{EF}_{\mathrm{c}, \mathrm{PCl}}$ is the emission factor $\left(\mathrm{kg} \mathrm{m}^{-3}\right)$ of $\mathrm{PCl}$ in commercial cooking. These constants are all based on $\mathrm{Wu}$ et al. (2018). The $\mathrm{PCl}$ fraction in $\mathrm{PM}_{2.5}$ from cooking is taken as $10 \%$, based on local measurements. $\mathrm{HCl}$ and $\mathrm{Cl}_{2}$ emissions from cooking are not considered in this study.

The sectoral emissions of $\mathrm{HCl}, \mathrm{Cl}_{2}$ and $\mathrm{PCl}$ are summarized in Table 1. The estimated $\mathrm{HCl}, \mathrm{Cl}_{2}$ and $\mathrm{PCl}$ emissions in Beijing are $1.89,0.07$ and $0.63 \mathrm{Gg}$, respectively. The $\mathrm{Cl}$ emissions estimated for 2014 by Fu et al. (2018) were used for other areas. This simplification is a good approximation because replacing coal with natural gas only occurred in Beijing, and reduction of coal consumption in surrounding regions was generally less than $15 \%$. In addition, strict control measures for biomass burning, cooking and municipal solid waste incineration have not been implemented in most regions yet. Emissions of conventional species for this study period are developed in a separate study that is currently under review and are summarized in Table S1 in the Supplement. 
Table 2. Major gas-phase and heterogeneous pathway of producing nitrate in original CMAQ, and newly added or revised heterogeneous reactions in improved CMAQ.

\begin{tabular}{|c|c|c|c|c|}
\hline Type & Reactions & no. & Reference & Comment \\
\hline \multicolumn{5}{|l|}{ Original CMAQ } \\
\hline $\begin{array}{l}\text { Gas-phase } \\
\text { chemistry }\end{array}$ & $\begin{array}{l}\mathrm{OH}+\mathrm{NO}_{2} \rightarrow \mathrm{HNO}_{3} \\
\mathrm{~N}_{2} \mathrm{O}_{5}+\mathrm{H}_{2} \mathrm{O} \rightarrow 2 \mathrm{HNO}_{3} \\
\mathrm{HO}_{2}^{*}+\mathrm{NO}_{3} \rightarrow 0.2 \mathrm{HNO}_{3}+0.8 \mathrm{OH}^{\bullet}+0.8 \mathrm{NO}_{2} \\
\mathrm{NO}_{3}+\mathrm{VOCs}^{*} \rightarrow \mathrm{HNO}_{3}\end{array}$ & $\begin{array}{l}\text { R1 } \\
\text { R7 } \\
\text { R8 } \\
\text { R9 }\end{array}$ & & \\
\hline $\begin{array}{l}\text { Heterogeneous } \\
\text { chemistry }\end{array}$ & $\begin{array}{l}\mathrm{N}_{2} \mathrm{O}_{5}(\mathrm{~g})+\mathrm{H}_{2} \mathrm{O}(\mathrm{aq}) \rightarrow 2 \mathrm{H}^{+}+2 \mathrm{NO}_{3}^{-} \\
2 \mathrm{NO}_{2}(\mathrm{~g})+\mathrm{H}_{2} \mathrm{O}(\mathrm{aq}) \rightarrow \mathrm{HONO}(\mathrm{g})+\mathrm{H}^{+}+\mathrm{NO}_{3}^{-}\end{array}$ & $\begin{array}{l}\text { R5 } \\
\text { R10 }\end{array}$ & & \\
\hline \multicolumn{5}{|l|}{ Improved CMAQ } \\
\hline $\begin{array}{l}\text { Newly added } \\
\text { or revised } \\
\text { heterogeneous } \\
\text { reactions }\end{array}$ & $\begin{array}{l}\mathrm{N}_{2} \mathrm{O}_{5}(\mathrm{~g})+\mathrm{H}_{2} \mathrm{O}(\mathrm{aq})+\mathrm{Cl}^{-}(\mathrm{aq}) \rightarrow \mathrm{ClNO}_{2}(\mathrm{~g})+\mathrm{NO}_{3}^{-} \\
2 \mathrm{NO}_{2}(\mathrm{~g})+\mathrm{Cl}^{-} \rightarrow \mathrm{ClNO}(\mathrm{g})+\mathrm{NO}_{3}^{-} \\
\mathrm{NO}_{3}(\mathrm{~g})+2 \mathrm{Cl}^{-} \rightarrow \mathrm{Cl}_{2}(\mathrm{~g})+\mathrm{NO}_{3}^{-} \\
\mathrm{O}_{3}(\mathrm{~g})+2 \mathrm{Cl}^{-}+\mathrm{H}_{2} \mathrm{O}(\mathrm{aq}) \rightarrow \mathrm{Cl}_{2}(\mathrm{~g})+\mathrm{O}_{2}(\mathrm{~g})+2 \mathrm{OH}^{-} \\
2 \mathrm{OH}(\mathrm{g})+2 \mathrm{Cl}^{-} \rightarrow \mathrm{Cl}_{2}(\mathrm{~g})+2 \mathrm{OH}^{-} \\
\mathrm{ClONO}_{2}(\mathrm{~g})+\mathrm{Cl}^{-} \rightarrow \mathrm{Cl}_{2}(\mathrm{~g})+\mathrm{NO}_{3}^{-} \\
\mathrm{HOCl}(\mathrm{g})+\mathrm{Cl}^{-}+\mathrm{H}^{+} \rightarrow \mathrm{Cl}_{2}(\mathrm{~g})+\mathrm{H}_{2} \mathrm{O} \\
\mathrm{ClNO}_{2}(\mathrm{~g})+\mathrm{Cl}^{-}+\mathrm{H}^{+} \rightarrow \mathrm{Cl}_{2}(\mathrm{~g})+\mathrm{HONO}(\mathrm{g})(\mathrm{pH}<2.0) \\
\mathrm{ClNO}_{2}(\mathrm{~g})+\mathrm{H}_{2} \mathrm{O}(\mathrm{aq}) \rightarrow \mathrm{Cl}^{-}+\mathrm{NO}_{3}^{-}+2 \mathrm{H}^{+}(\mathrm{pH} \geq 2.0)\end{array}$ & $\begin{array}{l}\text { R6 } \\
\text { R11 } \\
\text { R12 } \\
\text { R13 } \\
\text { R14 } \\
\text { R15 } \\
\text { R16 } \\
\text { R17 } \\
\text { R18 }\end{array}$ & $\begin{array}{l}\text { Bertram and Thornton (2009) } \\
\text { Abbatt and Waschewsky (1998) } \\
\text { Rudich et al. (1996) } \\
\text { Abbatt and Waschewsky (1998) } \\
\text { George and Abbatt (2010) } \\
\text { Deiber et al. (2004) } \\
\text { Pratte and Rossi (2006) } \\
\text { Riedel et al. (2012) } \\
\text { Rossi (2003) }\end{array}$ & $\begin{array}{l}\text { Revise } \mathrm{R} 5 \\
\text { Revise } \mathrm{R} 10 \\
\text { Increase } \mathrm{NO}_{3}^{-} \\
\text {Affect } \mathrm{OH} \\
\text { Affect } \mathrm{OH} \\
\text { Affect OH } \\
\text { Affect OH } \\
\text { Affect OH } \\
\text { Increase } \mathrm{NO}_{3}^{-}\end{array}$ \\
\hline
\end{tabular}

* Different VOC species. In the SAPRC-11 mechanism, the VOC species include CCHO (acetaldehyde), RCHO (lumped C3+ aldehydes), GLY (glyoxal), MGLY (methylglyoxal), PHEN (phenols), BALD (aromatic aldehydes), MACR (methacrolein) and IPRD (lumped isoprene product species).

\subsection{Chlorine-related heterogeneous reactions}

The heterogeneous reactions in original CMAQ (version 5.0.1) are not related to chlorine species. In this study, the original heterogeneous reactions of $\mathrm{N}_{2} \mathrm{O}_{5}$ and $\mathrm{NO}_{2}$ (Reactions R5 and R10 in Table 2) are replaced with a revised version which includes production of $\mathrm{ClNO}_{2}$ from CPs (Reactions R6 and R11 in Table 2). In Reaction (R6), the molar yield of $\mathrm{ClNO}_{2}\left(\phi_{\mathrm{ClNO}_{2}}\right)$ is represented as Eq. (3) (Bertram and Thornton, 2009):

$\phi_{\mathrm{ClNO}_{2}}=\left(1+\frac{\left[\mathrm{H}_{2} \mathrm{O}\right]}{483 \times\left[\mathrm{Cl}^{-}\right]}\right)^{-1}$,

where $\left[\mathrm{H}_{2} \mathrm{O}\right]$ and $\left[\mathrm{Cl}^{-}\right]$are the molarities of liquid water and chloride $\left(\mathrm{mol} \mathrm{m}^{-3}\right)$, respectively.

In addition, laboratory observations confirmed that the heterogeneous uptake of some oxidants (such as $\mathrm{O}_{3}$ and $\mathrm{OH}$ ) and reactive chlorine species (such as $\mathrm{ClNO}_{2}, \mathrm{HOCl}$ and $\mathrm{ClONO}_{2}$ ) could also occur in CPs to produce $\mathrm{Cl}_{2}$. These reactions are implemented in the model and summarized in Table 2 as Reactions (R13)-(R18). Note that the products from the heterogeneous uptake of $\mathrm{ClNO}_{2}$ in CPs vary with particle acidity (Riedel et al., 2012; Rossi, 2003). It generates $\mathrm{Cl}_{2}$ under the condition of the $\mathrm{pH}$ being lower than 2 but produces nitrate and chloride under higher $\mathrm{pH}$ conditions. The reaction rates of the heterogeneous reactions are parameterized as first-order reactions, with the rate of change of gasphase species concentrations determined by Eq. (4) (Ying et al., 2015):

$\frac{\mathrm{d} C}{\mathrm{~d} t}=-\frac{1}{4}(v \gamma A) C=-k^{\mathrm{I}} C$,

where $C$ represents the concentration of species, $v$ represents the thermal velocity of the gas molecules $\left(\mathrm{m} \mathrm{s}^{-1}\right), A$ is the CMAQ-predicted wet aerosol surface area concentration $\left(\mathrm{m}^{2} \mathrm{~m}^{-3}\right)$ and $\gamma$ represents the uptake coefficient. For all gas phases, for species (except $\mathrm{ClNO}_{2}$ ) involved in the heterogeneous reactions (Reactions R6 and R11-R18), a simple analytical solution can be used to update their concentrations from time $t_{0}$ to $t_{0}+\Delta t:[C]_{t_{0}+\Delta t}=[C]_{t_{0}} \exp \left(-k^{\mathrm{I}} \Delta t\right)$, where $\Delta t$ is the operator-splitting time step for heterogeneous reactions.

The rate of change of $\mathrm{ClNO}_{2}$ includes both removal and production terms, as shown in Eq. (5):

$$
\begin{aligned}
\frac{\mathrm{d}\left[\mathrm{ClNO}_{2}\right]}{\mathrm{d} t} & =-k_{i}^{\mathrm{I}}\left[\mathrm{ClNO}_{2}\right]+k_{6}^{\mathrm{I}} \phi_{\mathrm{ClNO}_{2}}\left[\mathrm{~N}_{2} \mathrm{O}_{5}\right] \\
& =-k_{i}^{\mathrm{I}}\left[\mathrm{ClNO}_{2}\right]+k_{6}^{\mathrm{I}} \phi_{\mathrm{ClNO}_{2}}\left[\mathrm{~N}_{2} \mathrm{O}_{5}\right]_{t_{0}} \exp \left(-k_{6}^{\mathrm{I}} t\right) .
\end{aligned}
$$

Assuming that $\phi_{\mathrm{ClNO}_{2}}$ is a constant, an analytical solution for Eq. (5) can be obtained, as shown in Eq. (6):

$$
\begin{aligned}
& {\left[\mathrm{ClNO}_{2}\right]_{t_{0}+\Delta t}=\left[\mathrm{ClNO}_{2}\right]_{t_{0}} \exp \left(-k_{i}^{\mathrm{I}} \Delta t\right)} \\
& +\frac{k_{6}^{\mathrm{I}} \phi_{\mathrm{ClNO}_{2}}\left[\mathrm{~N}_{2} \mathrm{O}_{5}\right]_{t_{0}}}{k_{i}^{\mathrm{I}}-k_{6}^{\mathrm{I}}}\left[\exp \left(-k_{6}^{\mathrm{I}} \Delta t\right)-\exp \left(-k_{i}^{\mathrm{I}} \Delta t\right)\right],
\end{aligned}
$$

where $k_{i}^{\mathrm{I}}$ represents the pseudo-first-order rate coefficient of either Reaction (R17) or (R18), depending on $\mathrm{pH}$. 
The uptake coefficients $\gamma$ of gaseous species are obtained from published laboratorial studies. In the original CMAQ, the uptake coefficient of $\mathrm{N}_{2} \mathrm{O}_{5}$ is determined as a function of the concentrations of $\left(\mathrm{NH}_{4}\right)_{2} \mathrm{SO}_{4}, \mathrm{NH}_{4} \mathrm{HSO}_{4}$ and $\mathrm{NH}_{4} \mathrm{NO}_{3}$ (Davis et al., 2008). In this study, the parameterization dependent on $\mathrm{PCl}$ and $\mathrm{NO}_{3}^{-}$by Bertram and Thornton (2009) (Eq. 7) is used:

$$
\begin{aligned}
& \gamma_{\mathrm{N}_{2} \mathrm{O}_{5}}= \\
& \left\{\begin{array}{l}
0.02, \text { for frozen aerosols } \\
3.2 \times 10^{-8} K_{\mathrm{f}}\left[1-\left(1+\frac{6 \times 10^{-2}\left[\mathrm{H}_{2} \mathrm{O}\right]}{\left[\mathrm{NO}_{3}^{-}\right]}+\frac{29[\mathrm{Cl}]}{\left[\mathrm{NO}_{3}^{-}\right]}\right)^{-1}\right]
\end{array}\right.
\end{aligned}
$$

In the above equation, $K_{\mathrm{f}}$ is parameterized function based on the molarity of water: $K_{\mathrm{f}}=1.15 \times 10^{6}\left(1-e^{-0.13\left[\mathrm{H}_{2} \mathrm{O}\right]}\right)$. $\mathrm{NO}_{3}^{-}$and $\mathrm{Cl}^{-}$concentrations are also molar. The uptake coefficient of $\mathrm{OH}$ is expressed in Eq. (8) as a function of the concentration of $\mathrm{PCl}$ following the IUPAC (International Union of Pure and Applied Chemistry, available at http://iupac.poleether.fr/htdocs/datasheets/pdf/O-H_ halide_solutions_VI.A2.1.pdf, last access: 5 June 2018).

$\gamma_{\mathrm{OH}}=\min \left(0.04 \times \frac{\left[\mathrm{Cl}^{-}\right]}{1000 \times M}, 1\right)$,

where $M$ represents the volume of liquid water in aerosol volume $\left(\mathrm{m}^{3} \mathrm{~m}^{-3}\right)$. For frozen particles, the uptake coefficient is limited to 0.02, as used in the original CMAQ model.

The uptake coefficients of $\mathrm{O}_{3}, \mathrm{NO}_{3}, \mathrm{NO}_{2}, \mathrm{HOCl}, \mathrm{ClNO}_{2}$ and $\mathrm{ClONO}_{2}$ are treated as constants. Among of them, the $\gamma$ values of $\mathrm{NO}_{3}, \mathrm{NO}_{2}, \mathrm{HOCl}$ and $\mathrm{ClONO}_{2}$ are set as $3 \times 10^{-3}$, $1 \times 10^{-4}, 1.09 \times 10^{-3}$ and 0.16 based on laboratory measurements (Rudich et al., 1996; Abbatt and Waschewsky, 1998; Pratte and Rossi, 2006; Gebel and Finlayson-Pitts, 2001). A preliminary value of $10^{-3}$ in the daytime and $10^{-5}$ during the nighttime is chosen for the $\mathrm{O}_{3}$ uptake coefficient. The daytime $\gamma_{\mathrm{O}_{3}}$ is based on the analysis of the $\mathrm{Cl}_{2}$ production rate in a hypothesized geochemical cycle of reactive inorganic chlorine in the marine boundary layer by Keene et al. (1990). The lower nighttime value was also recommended by Keene et al. (1990), who noted that $\mathrm{Cl}_{2}$ production in the marine boundary layer is lower at night. The uptake coefficient of $\mathrm{ClNO}_{2}$ depends on the particle acidity, with the value of $2.65 \times 10^{-6}$ for Reaction (R17) and $6 \times 10^{-3}$ for Reaction (R18) (Roberts et al., 2008).

\subsection{CMAQ model configuration}

These heterogeneous reactions of chlorine are incorporated into a revised CMAQ based on the CMAQ version 5.0.1 to simulate the distribution of nitrate concentration in Beijing from 11 to 15 June 2017. The revised CMAQ model without heterogeneous reactions of chlorine has been described in detail by Ying et al. (2015) and Hu et al. (2016, 2017). In summary, the gas-phase chemical mechanism in the revised
CMAQ model is based on the SAPRC-11 (Carter and Heo, 2013) with comprehensive inorganic chlorine chemistry. Reactions of the $\mathrm{Cl}$ radical with several major VOCs, which lead to production of $\mathrm{HCl}$, are also included. The aerosol module is based on AERO6, with an updated treatment of the $\mathrm{NO}_{2}$ and $\mathrm{SO}_{2}$ heterogeneous reaction and formation of secondary organic aerosol from isoprene epoxides. Three-level nested domains with the resolutions of 36, 12 and $4 \mathrm{~km}$ using Lambert conformal conic projection $(173 \times 136,135 \times 228$ and $60 \times 66$ grid cells) are chosen in this work (the domains; see Fig. S1). The two true latitudes are set to 25 and $40^{\circ} \mathrm{N}$, and the origin of the domain is set at $34^{\circ} \mathrm{N}, 110^{\circ} \mathrm{E}$. The leftbottom coordinates of the outmost domain are positioned at $x=-3114 \mathrm{~km}, y=-2448 \mathrm{~km}$. The BASE case (heterogeneous reactions of $\mathrm{Cl}$ turned off) and HET case (all heterogeneous reactions enabled) are compared to evaluate the impact of heterogeneous chlorine chemistry on nitrate formation.

\section{Results}

\subsection{Model performance evaluation}

Predicted $\mathrm{O}_{3}, \mathrm{NO}_{2}$ and $\mathrm{PM}_{2.5}$ concentrations from the BASE case simulation are evaluated against monitoring data at 12 sites in Beijing (Table S2) in 11 to 15 June 2017. The average values for normalized mean bias (NMB) for $\mathrm{O}_{3}, \mathrm{NO}_{2}$ and $\mathrm{PM}_{2.5}$ across the 12 sites are $-8 \%,-7 \%$ and $-8 \%$, respectively, and $29 \%, 59 \%$ and $53 \%$ for normalized mean error (NME), respectively. Predicted hourly $\mathrm{Cl}_{2}, \mathrm{ClNO}_{2}$ and $\mathrm{N}_{2} \mathrm{O}_{5}$ concentrations were compared with observations measured at the Institute of Atmospheric Physics (IAP), Chinese Academy of Sciences $\left(39.98^{\circ} \mathrm{N}, 116.37^{\circ} \mathrm{E}\right)$, using a highresolution time-of-flight chemical ionization mass spectrometer (CIMS) from 11 to 15 June 2017 (for site description, instrument introduction and analytical method, please refer to the study by Zhou et al., 2018). Figure 1 shows that the concentrations of $\mathrm{Cl}_{2}$ and $\mathrm{ClNO}_{2}$ in the $\mathrm{BASE}$ case are rather low (close to 0 ), proving that the gas-phase chemistry is not the major pathway for producing $\mathrm{Cl}_{2}$ and $\mathrm{ClNO}_{2}$. By contrast, the simulated $\mathrm{Cl}_{2}$ and $\mathrm{ClNO}_{2}$ concentrations in HET case increase significantly; correspondingly the NMB and NME changes from $-100 \%$ to $-54 \%$ and $100 \%$ to $61 \%$ for $\mathrm{Cl}_{2}$ and from $-100 \%$ to $-58 \%$ and $100 \%$ to $62 \%$ for $\mathrm{ClNO}_{2}$, respectively (the particle surface area concentrations is scaled up by a factor of 5 during the daytime and 10 during the nighttime because this parameter is underestimated compared to the measured concentrations reported by Zhou et al., 2018). The simulations of $\mathrm{Cl}_{2}$ and $\mathrm{ClNO}_{2}$ are improved as the additional heterogeneous reactions prompt the production of gas-phase molecular chlorine. Overall, however, the $\mathrm{Cl}_{2}$ and $\mathrm{ClNO}_{2}$ concentrations are still underestimated. Both BASE and HET simulations generally capture the hourly $\mathrm{N}_{2} \mathrm{O}_{5}$ concentrations as well as the peak values (Fig. 1c) with similar overall NMB and NME values. 


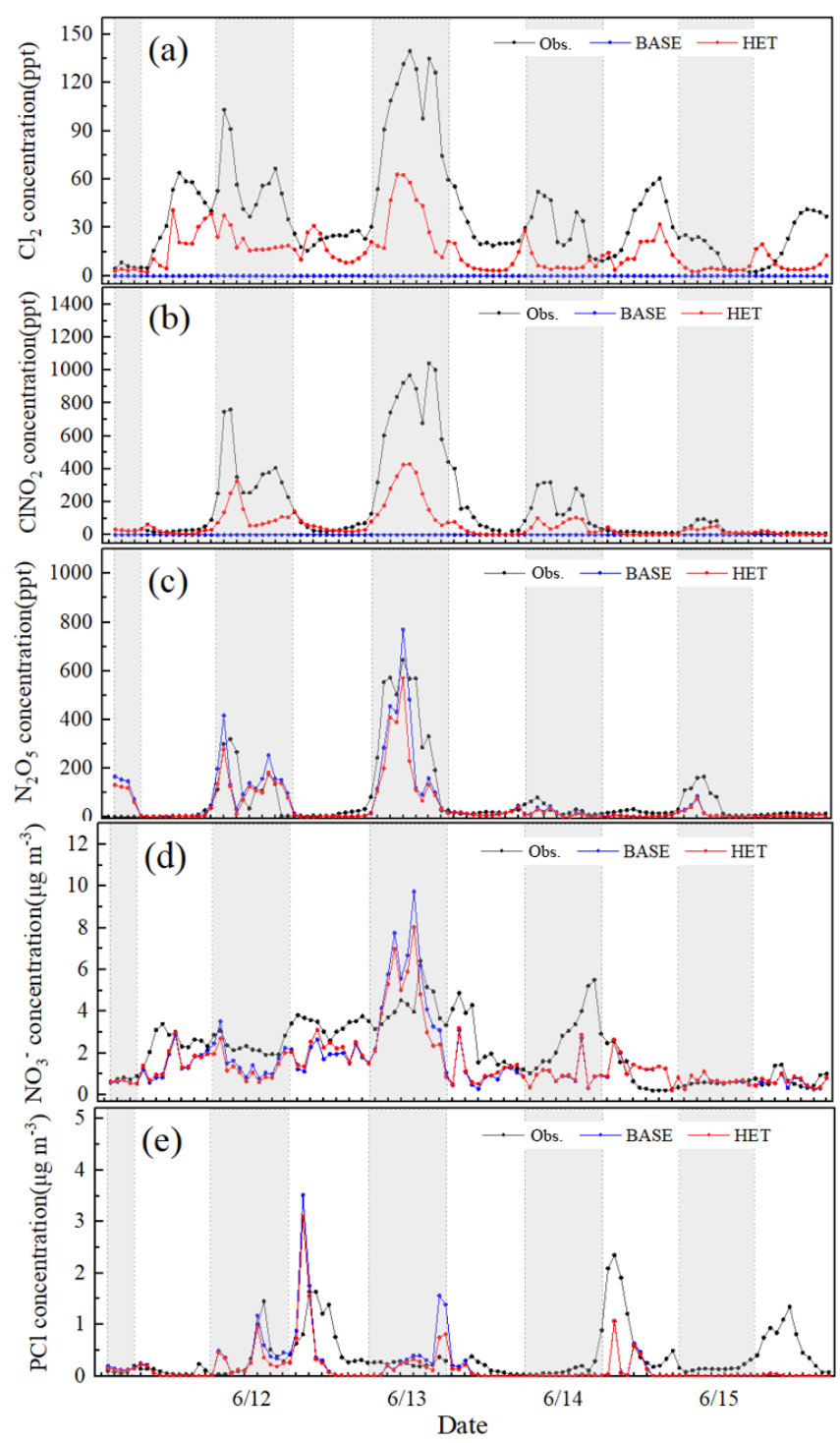

Figure 1. Comparison of observed hourly $\mathrm{Cl}_{2}, \mathrm{ClNO}_{2}, \mathrm{~N}_{2} \mathrm{O}_{5}$ (at the Institute of Atmospheric Physics, Chinese Academy of Sciences), $\mathrm{NO}_{3}^{-}$and $\mathrm{PCl}$ (at Tsinghua University) in urban Beijing with predictions from the BASE and the HET cases during 11-15 June 2017.

The uptake coefficient of $\mathrm{O}_{3}$ could be an important factor affecting the predicted $\mathrm{Cl}_{2}$ concentrations, as the heterogeneous reaction of $\mathrm{O}_{3}$ is found to be the major source of $\mathrm{Cl}_{2}$ during this period (see discussion in Sect. 3.2). The influence of different parametrizations of the uptake coefficient of $\mathrm{N}_{2} \mathrm{O}_{5}$ on $\mathrm{ClNO}_{2}$ and nitrate concentrations are also discussed in Sect. 3.2.

Predicted $\mathrm{NO}_{3}^{-}$and $\mathrm{PCl}$ concentrations are compared with observations measured at an adjacent monitoring site located at the rooftop of School of Environment building at Tsinghua University (THU; $40.00^{\circ} \mathrm{N}, 116.34^{\circ} \mathrm{E}$; about $5 \mathrm{~km}$ from the IAP) using an online analyzer of Monitoring for Aerosol and Gases in ambient Air (MARGA) from 11 to 15 June 2017.
According to Fig. 1d, the simulated nitrate concentration is slightly lower than the observations most of the time. From the evening hours of 12 June to the morning hours of 13 June, observed and simulated nitrate concentrations both increase significantly. The NMB and NME values of hourly nitrate for the HET case ( $-5 \%$ and $39 \%$, respectively) are slightly lower than those for the BASE case $(-10 \%$ and $46 \%)$ during this high-concentration period. The HET case also generally captures the day-to-day variation of $\mathrm{PCl}$ concentration and performs better than the BASE case, correspondingly the NMB and NME are reduced from $-48 \%$ and $72 \%$ to $-37 \%$ and $67 \%$. The substantial underestimation of $\mathrm{PCl}$ in the daytime on 15 June is likely caused by missing local emissions during this period.

\subsection{Impact of uptake coefficients of $\mathrm{O}_{3}$ and $\mathrm{N}_{2} \mathrm{O}_{5}$ on chlorine species and nitrate}

The uptake coefficients of $\mathrm{O}_{3}$ and $\mathrm{N}_{2} \mathrm{O}_{5}$ may be important factors affecting the accuracy of simulated nitrate concentrations. Some studies have confirmed that the reaction of $\mathrm{O}_{3}$ in CPs can indirectly affect the nitrate formation by increasing the atmospheric $\mathrm{Cl}_{2}$ and $\mathrm{OH}$ level (Li et al., 2016; Liu et al., 2018). According to Fig. 1a, the improved model still substantially underestimates the concentration of $\mathrm{Cl}_{2}$, which may be associated with the underestimation of the uptake coefficients of $\mathrm{O}_{3}$, which are empirical and have not been confirmed by laboratory studies. The uptake coefficients were increased by a factor of 10 ( 0.01 for daytime and $10^{-4}$ for nighttime) to evaluate the sensitivity of $\mathrm{Cl}_{2}$ production and nitrate formation to this parameter. Figure 2 shows that the simulated $\mathrm{Cl}_{2}$ and nitrate concentrations in daytime increase significantly (especially for $\mathrm{Cl}_{2}$ ) and can sometimes capture the peak value (such as the daytime peak on 14 June). However, although the NMB and $\mathrm{NME}$ of $\mathrm{Cl}_{2}$ and nitrate improve from $-18 \%$ and $39 \%$ to $1 \%$ and $28 \%$ when the new uptake coefficients are used, the simulated $\mathrm{Cl}_{2}$ concentrations are still quite different from the observations (such as during the daytime on 11 and 12 June; see Fig. 2). A non-constant parameterization of the uptake coefficients of $\mathrm{O}_{3}$ that considers the influence of $\mathrm{PCl}$ concentrations, meteorology conditions, etc., similar to those of $\mathrm{OH}$ and $\mathrm{N}_{2} \mathrm{O}_{5}$, might be needed. Further laboratory studies should be conducted to provide a better estimation of this important parameter.

Several parameterizations for the uptake coefficient of $\mathrm{N}_{2} \mathrm{O}_{5}$ have been developed for regional and global models and have been evaluated in several previous studies (Tham et al., 2018; McDuffie et al., 2018a, b). In addition to the parameterization of Bertram and Thornton (2009) used in the HET case, two additional simulations were performed to assess the impact of the uptake coefficient of $\mathrm{N}_{2} \mathrm{O}_{5}$ on nitrate formation. The first simulation uses the original CMAQ parameterization of Davis et al. (2008), and the second simulation uses a constant value of 0.09 , which is the upper limit of the $\mathrm{N}_{2} \mathrm{O}_{5}$ uptake coefficient derived by Zhou et al. (2018), 


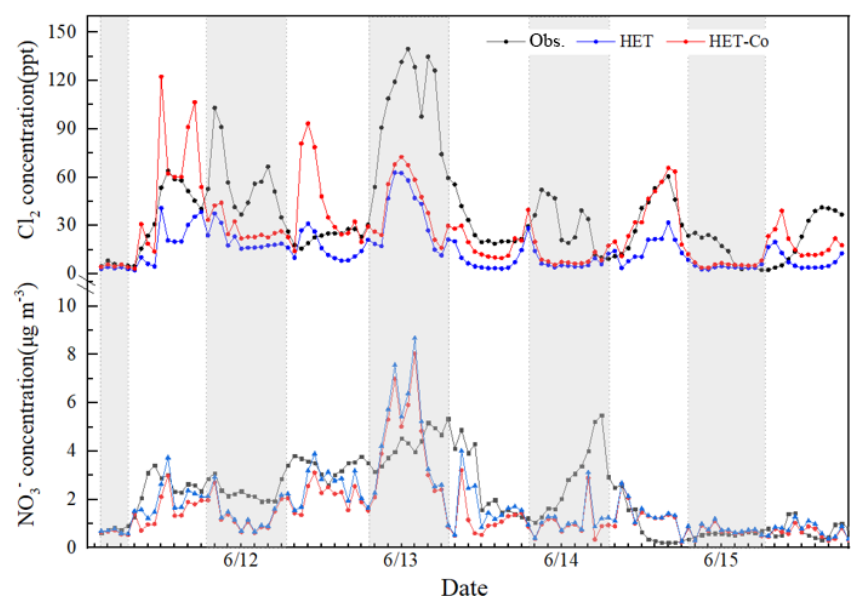

Figure 2. Comparison of observed and predicted $\mathrm{Cl}_{2}$ and $\mathrm{NO}_{3}^{-}$concentrations under different uptake coefficient of $\mathrm{O}_{3}$ (HET: daytime is $\gamma_{\mathrm{O}_{3}}=1 \times 10^{-3}$, nighttime is $\gamma_{\mathrm{O}_{3}}=1 \times 10^{-5}$; HET-Co: daytime is $\gamma_{\mathrm{O}_{3}}=1 \times 10^{-2}$, nighttime is $\left.\gamma_{\mathrm{O}_{3}}=1 \times 10^{-4}\right)$.

based on observations. The results from the simulations with the parameterization of Bertram and Thornton (2009) generally agree with the results using those based on Davis et al. (2008) .The application of a larger and fixed $\mathrm{N}_{2} \mathrm{O}_{5}$ uptake coefficient leads to slightly better results, which might reflect the fact that the $\mathrm{N}_{2} \mathrm{O}_{5}$ concentrations are underestimated. Using the uptake coefficient of 0.09 can generally increase the concentration of nitrate in some periods, but it also leads to significant increase in the nitrate level (such as nighttime on 12-13 June and 13-14 June), which is 4-6 times higher than those based on Bertram and Thornton (2009). Overall, predicted nitrate concentrations are sensitive to changes in the changes in $\gamma_{\mathrm{N}_{2}} \mathrm{O}_{5}$, with an increase of approximately $50 \%$ in the nitrate when a constant of $\gamma_{\mathrm{N}_{2} \mathrm{O}_{5}}$ of 0.09 is used.

\subsection{Spatial distributions of nitrate and chlorine species concentrations}

The regional distributions of averaged $\mathrm{Cl}_{2}, \mathrm{ClNO}_{2}, \mathrm{~N}_{2} \mathrm{O}_{5}$ and $\mathrm{NO}_{3}^{-}$concentration from 11 to 15 June for the HET case are shown in Fig. 3. Compared to the BASE case, the episodeaverage concentrations of $\mathrm{Cl}_{2}$ and $\mathrm{ClNO}_{2}$ from the HET case increase significantly in the eastern region of Beijing, reaching up to 23 and $71 \mathrm{ppt}$ from near zero (Fig. 3a and b). High concentrations are not found in the southern region with intensive emissions of chlorine species (Fig. S2). The production of $\mathrm{ClNO}_{2}$ requires the presence of chloride, $\mathrm{NO}_{2}$ and $\mathrm{O}_{3}$. In the areas close to the fresh emissions, $\mathrm{O}_{3}$ is generally low (Fig. S3), and the production of $\mathrm{NO}_{3}$ (hence $\mathrm{N}_{2} \mathrm{O}_{5}$ and $\mathrm{ClNO}_{2}$ ) is limited. Therefore, the production rate of $\mathrm{ClNO}_{2}$ is generally low in areas affected by fresh emissions. Since the contribution of direct emissions to $\mathrm{Cl}_{2}$ is low and it is predominantly produced secondarily in the atmosphere, high levels of $\mathrm{Cl}_{2}$ are also found away from the fresh emissions.

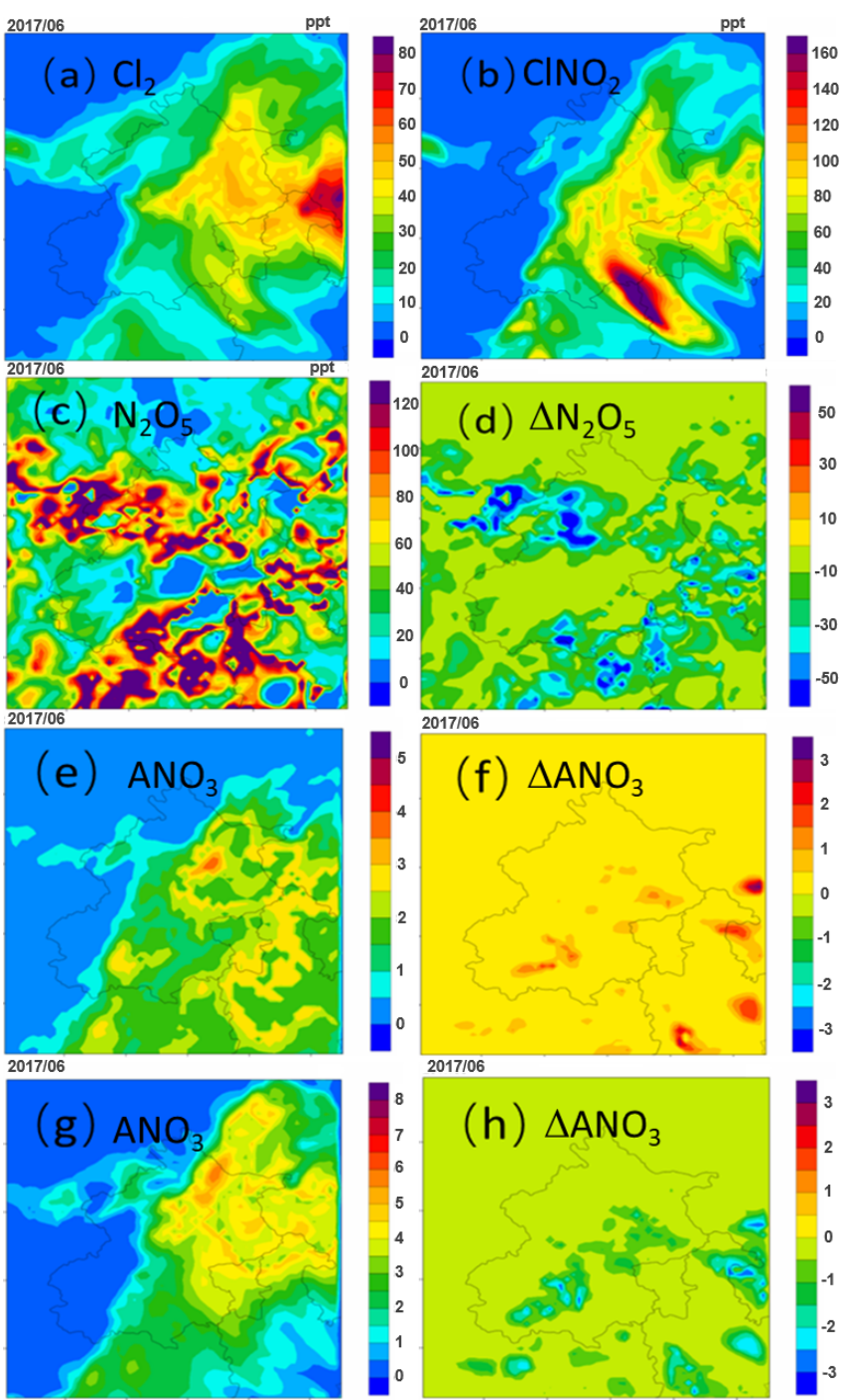

Figure 3. Spatial distributions of episode-average (a) $\mathrm{Cl}_{2}$, (b) $\mathrm{ClNO}_{2}$, (c) $\mathrm{N}_{2} \mathrm{O}_{5}$, (e) daytime nitrate $\left(\mathrm{ANO}_{3}\right)$ and (g) nighttime nitrate concentrations from 11-15 June 2017, and the differences in the episode-average (d) $\mathrm{N}_{2} \mathrm{O}_{5}$ (HET case minus BASE case), (f) daytime nitrate and (g) nighttime nitrate (units are $\mu \mathrm{g} \mathrm{m}^{-3}$ ).

The spatial distribution of $\mathrm{N}_{2} \mathrm{O}_{5}$ concentrations differs from that of other species (Fig. 3c). While the concentrations of most of the species are higher in the southern region, the $\mathrm{N}_{2} \mathrm{O}_{5}$ concentrations are lower in some parts of this region. This is because the $\mathrm{O}_{3}$ concentration in the core urban areas is low due to high $\mathrm{NO}_{x}$ emissions. The $\mathrm{N}_{2} \mathrm{O}_{5}$ concentrations from the HET case are approximately $16 \%$ lower on average (Fig. 3d) because the Bertram and Thornton (2009) parameterization used in the HET case generally gives higher uptake coefficients than the parameterization of Davis et al. (2008) used in the BASE case (Table 3).

Although the higher uptake coefficients of $\mathrm{N}_{2} \mathrm{O}_{5}$ in the HET case facilitate faster conversion of $\mathrm{N}_{2} \mathrm{O}_{5}$ to nitrate, the nitrate concentrations do not always increase. During day- 


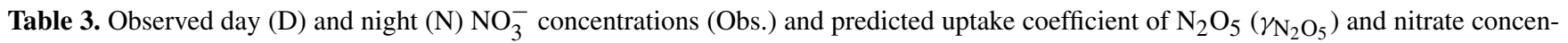
trations (Pred.) using the parameterizations of $\gamma_{\mathrm{N}_{2} \mathrm{O}_{5}}$ by Bertram and Thornton (2009; Scenario 1), Davis et al. (2008; Scenario 2) and the upper-limit value derived by Zhou et al. (2018; Scenario 3) from 11 to 15 June 2017.

\begin{tabular}{lrrr|rr|rr}
\hline & $\mathrm{NO}_{3}^{-}$ & \multicolumn{2}{c|}{ Scenario 1 } & \multicolumn{2}{c|}{ Scenario 2 } & \multicolumn{2}{c}{ Scenario 3 } \\
\cline { 3 - 8 } & Obs. & $\gamma_{\mathrm{N}_{2} \mathrm{O}_{5}}$ & Pred. & $\gamma_{\mathrm{N}_{2} \mathrm{O}_{5}}$ & Pred. & $\gamma_{\mathrm{N}_{2} \mathrm{O}_{5}}$ & Pred. \\
\hline 06/11-D & 2.54 & 0.033 & 1.59 & 0.008 & 1.32 & 0.09 & 2.17 \\
06/11-12-N & 2.42 & 0.043 & 1.67 & 0.037 & 1.37 & 0.09 & 2.12 \\
06/12-D & 3.39 & 0.028 & 2.16 & 0.032 & 2.74 & 0.09 & 3.13 \\
06/12-13-N & 4.24 & 0.021 & 4.02 & 0.022 & 4.05 & 0.09 & 6.04 \\
06/13-D & 2.57 & 0.012 & 1.18 & 0.008 & 1.06 & 0.09 & 2.47 \\
06/13-14-N & 4.10 & 0.022 & 4.45 & 0.022 & 4.45 & 0.09 & 7.13 \\
06/14-D & 0.95 & 0.001 & 1.34 & 0.001 & 1.33 & 0.09 & 1.64 \\
06/14-15-N & 2.75 & 0.013 & 1.00 & 0.007 & 0.96 & 0.09 & 2.33 \\
06/15-D & 0.75 & 0.001 & 0.66 & 0.001 & 0.66 & 0.09 & 1.11 \\
\hline
\end{tabular}

time hours, nitrate concentrations in the HET case increase due to higher $\mathrm{OH}$ (Fig. 3e and f; for increased $\mathrm{OH}$, see Fig. S4). During the nighttime, in contrast, the nitrate concentration decreases significantly in some regions by about $22 \%$, mainly due to lower molar yield of nitrate from the $\mathrm{N}_{2} \mathrm{O}_{5}$ heterogeneous reaction in the HET case (Fig. 3g and h). Although $\mathrm{ClNO}_{2}$ produced in the $\mathrm{N}_{2} \mathrm{O}_{5}$ reaction also produces nitrate through a heterogenous reaction when the particle $\mathrm{pH}$ is above 2, which is true for most regions (see Fig. S5), the uptake coefficient of $\mathrm{ClNO}_{2}$ is significantly lower than that of $\mathrm{N}_{2} \mathrm{O}_{5}\left(0.01-0.09\right.$ for $\mathrm{N}_{2} \mathrm{O}_{5}$ and $6 \times 10^{-3}$ for $\left.\mathrm{ClNO}_{2}\right)$, leading to an overall decrease in nitrate production. As the $\mathrm{ClNO}_{2}$ production from the heterogeneous reaction leads to less $\mathrm{N}_{2} \mathrm{O}_{5}$ conversion to non-relative nitrate, it may change the overall lifetime of $\mathrm{NO}_{x}$ and its transport distances. The magnitude of this change and its implications on ozone and $\mathrm{PM}_{2.5}$ in local and downwind areas should be further studied.

\subsection{Relationship between nitrate formation and chlorine chemistry}

Nitrate production from the homogeneous and heterogeneous pathways in Beijing is approximated by the difference in predicted nitrate concentrations between the BASE or HET case and a sensitivity case without heterogenous reactions. Averaging over the $5 \mathrm{~d}$ period, approximately $58 \%$ of the nitrate originates from $\mathrm{HNO}_{3}$ gas-to-particle partitioning and $42 \%$ is from heterogeneous reactions (Fig. 4). This conclusion generally agrees with measurements at Peking University (PKU; $52 \%$ from the heterogeneous process and $48 \%$ from $\mathrm{HNO}_{3}$ partitioning) on 4 polluted days (average in September 2016 reported by Wang et al., 2017). Slightly higher contributions of the homogeneous pathway in this study are expected because of high $\mathrm{OH}$ concentrations during the day and lower particle surface areas at night.

The nitrate formation from different homogeneous and heterogeneous pathways in the BASE case and HET case are further studied. Contributions of different gas-phase pathways are determined using the process analysis tool in CMAQ. Contributions of different heterogeneous pathways are determined using a zero-out method that turns off one heterogeneous pathway at a time in a series of sensitivity simulations. Figure 4 shows that the reaction of $\mathrm{OH}$ and $\mathrm{NO}_{2}$ is always the major pathway for the formation of nitrate through homogeneous formation of $\mathrm{HNO}_{3}$ and gasto-particle partitioning. However, its nitrate production rate through this homogeneous pathway decreases significantly from daytime to nighttime (from 1.81 to $0.33 \mu \mathrm{g} \mathrm{m}^{-3} \mathrm{~h}^{-1}$ on average). The nitrate production from other $\mathrm{HNO}_{3}$ partitioning pathways in the daytime is negligible. During the nighttime, homogeneous reaction of $\mathrm{N}_{2} \mathrm{O}_{5}$ with water vapor accounts for approximately $5 \%$ of the overall homogeneous nitrate formation. For the heterogeneous pathways, daytime production rate is approximately $0.6 \mu \mathrm{g} \mathrm{m}^{-3} \mathrm{~h}^{-1}$, with onethird of the contributions being from $\mathrm{NO}_{2}$ and two-thirds from $\mathrm{N}_{2} \mathrm{O}_{5}$. Nighttime production on nitrate from the heterogeneous pathways is approximately $3.1 \mu \mathrm{g} \mathrm{m}^{-3} \mathrm{~h}^{-1}$, of which $85 \%$ is due to $\mathrm{N}_{2} \mathrm{O}_{5}$ and $15 \%$ is due to $\mathrm{NO}_{2}$.

Comparing the BASE case and the HET case shows that, when the chlorine chemistry is included, the gaseous $\mathrm{HNO}_{3}$ produced by $\mathrm{OH}$ reacting with $\mathrm{NO}_{2}$ increases significantly in the HET case. Correspondingly, the nitrate production rate reaches up to $2.04 \mu \mathrm{g} \mathrm{m}^{-3} \mathrm{~h}^{-1}$ in the daytime due to increased atmospheric $\mathrm{OH}$ concentrations predicted by the chlorine reactions. Similar conclusions are also obtained by Li et al. (2016) and Liu et al. (2017) based on observations and model simulations. The heterogeneous production of nitrate from the reaction of $\mathrm{N}_{2} \mathrm{O}_{5}$ uptake decreases by approximately $27 \%$ in the HET case due to the production of gasphase $\mathrm{ClNO}_{2}$. According to the study by Sarwar et al. (2012, 2014), including the heterogeneous reaction of $\mathrm{N}_{2} \mathrm{O}_{5}$ with $\mathrm{PCl}$ decreased the nocturnal nitrate concentration by $11 \%$ $21 \%$ in the United States, which was slightly less than the current study for Beijing. It is likely because $\mathrm{PCl}$ concentra- 


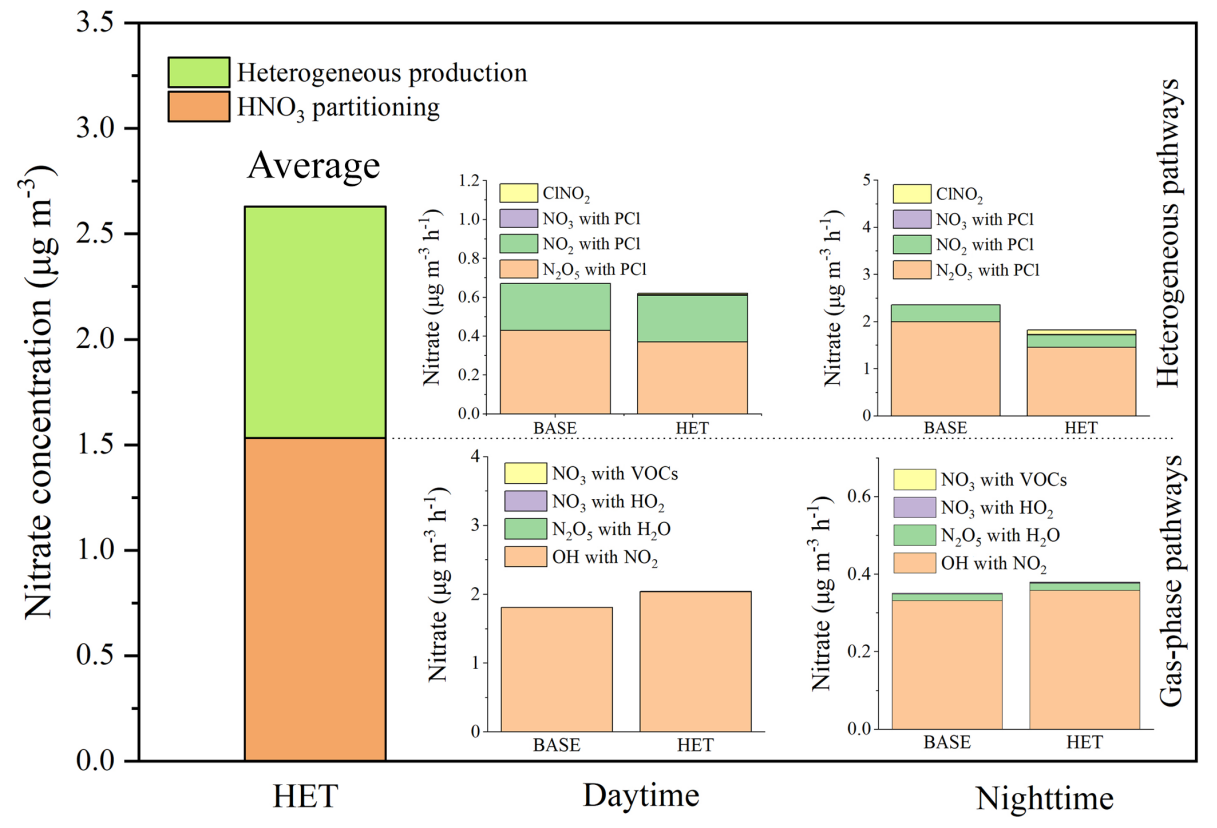

Figure 4. Contributions of different homogeneous and heterogeneous pathways to nitrate formation.

tions in the United States are significantly lower than those in Beijing (the monthly $\mathrm{PCl}$ concentration is $0.06 \mu \mathrm{g} \mathrm{m}^{-3}$ in the United States against $\sim 1 \mu \mathrm{g} \mathrm{m}^{-3}$ in Beijing) so that $\mathrm{PCl}$ is depleted quickly. The contributions of $\mathrm{NO}_{2}$ uptake to nitrate also decrease by $22 \%$ because of the lower rate constant of the reaction of $\mathrm{NO}_{2}$ with $\mathrm{PCl}$. In contrast, the contribution of $\mathrm{ClNO}_{2}$ reacts with the particle surface to nitrate production increases of $6 \%$ in the HET case. The overall nitrate concentration in the HET case is about $22 \%$ higher than that in the BASE case during this study period.

\section{Conclusions}

In this work, a modified CMAQ model incorporating heterogeneous reactions for the production of molecular chlorine and other reactive chlorine species is developed, and its impact on the nitrate formation predictions is evaluated. The contributions from different homogenous and heterogeneous pathways to nitrate formation are also quantified. High concentrations of $\mathrm{Cl}_{2}$ and $\mathrm{ClNO}_{2}$ do not occur in the southern part of the Beijing-Tianjin-Hebei region with intensive emissions of chlorine species, as higher concentrations of $\mathrm{O}_{3}$ and $\mathrm{N}_{2} \mathrm{O}_{5}$ associated with the heterogeneous formation of these species generally occurred in the downwind areas. CTMs without a complete treatment of the chlorine chemistry can underestimate daytime nitrate formation from the homogeneous pathways, particularly from $\mathrm{HNO}_{3}$ gas-toparticle partitioning due to underestimation of $\mathrm{OH}$ concentrations and overestimation of the nighttime nitrate formation from the heterogeneous pathways due to missing chlorine heterogeneous chemistry.
Data availability. The data in this study are available from the authors upon request (shxwang@tsinghua.edu.cn).

Supplement. The supplement related to this article is available online at: https://doi.org/10.5194/acp-19-6737-2019-supplement.

Author contributions. XQ, QY, SW and JH designed the study. YS, BL, AS and XY provided observation data. XQ, QY, SW, JZ, QX, DD, LD and JX analyzed data. XQ, QY and SW wrote the paper.

Competing interests. The authors declare that they have no conflict of interest.

Acknowledgements. The simulations were completed on the Explorer 100 cluster system of the Tsinghua National Laboratory for Information Science and Technology.

Financial support. This research has been supported by the National Natural Science Foundation of China (grant no. 21625701), the China Postdoctoral Science Foundation (grant no. 2018M641385), the National Research Program for Key Issue in Air Pollution Control (grant nos. DQGG0301, DQGG0501) and the National Key R\&D Program of China (grant nos. 2018YFC0213805, 2018YFC0214006).

Review statement. This paper was edited by Andreas Hofzumahaus and reviewed by three anonymous referees. 


\section{References}

Abbatt, J. P. D. and Waschewsky, G. C.G.: Heterogeneous interactions of $\mathrm{HOBr}, \mathrm{HNO}_{3}, \mathrm{O}_{3}$, and $\mathrm{NO}_{2}$ with deliquescent $\mathrm{NaCl}$ aerosols at room temperature, J. Phys. Chem A., 102, 3719$3725,1998$.

Bertram, T. H. and Thornton, J. A.: Toward a general parameterization of $\mathrm{N}_{2} \mathrm{O}_{5}$ reactivity on aqueous particles: the competing effects of particle liquid water, nitrate and chloride, Atmos. Chem. Phys., 9, 8351-8363, https://doi.org/10.5194/acp-9-8351-2009, 2009.

Brown, S. S. and Stutz, J.: Nighttime radical observations and chemistry, Chem. Soc. Rev., 41, 6405-6447, 2012.

Carter, W. P. and Heo, G.: Development of revised SAPRC aromatics mechanisms, Atmos. Environ., 77, 404-414, 2013.

Chang, X., Wang, S., Zhao, B., Cai, S., and Hao, J.: Assessment of inter-city transport of particulate matter in the BeijingTianjin-Hebei region, Atmos. Chem. Phys., 18, 4843-4858, https://doi.org/10.5194/acp-18-4843-2018, 2018.

Davis, J. M., Bhave, P. V., and Foley, K. M.: Parameterization of $\mathrm{N}_{2} \mathrm{O}_{5}$ reaction probabilities on the surface of particles containing ammonium, sulfate, and nitrate, Atmos. Chem. Phys., 8, 52955311, https://doi.org/10.5194/acp-8-5295-2008, 2008.

Deiber, G., George, Ch., Le Calvé, S., Schweitzer, F., and Mirabel, Ph.: Uptake study of $\mathrm{ClONO}_{2}$ and $\mathrm{BrONO}_{2}$ by Halide containing droplets, Atmos. Chem. Phys., 4, 1291-1299, https://doi.org/10.5194/acp-4-1291-2004, 2004.

Deng, S., Zhang, C., Liu, Y., Cao, Q., Xu, Y. Y., Wang, H. L., and Zhang, F.: A Full-Scale Field Study on Chlorine Emission of Pulverized Coal-Fired Power Plants in China, Research of Environmental Science, 27, 127-133, 2014 (in Chinese).

Faxon, C. B., Bean, J. K., and Hildebrandt R. L.: Inland Concentrations of $\mathrm{Cl}_{2}$ and $\mathrm{ClNO}_{2}$ in Southeast Texas Suggest Chlorine Chemistry Significantly Contributes to Atmospheric Reactivity, Atmosphere, 6, 1487-1506, 2015.

Fu, X., Wang, S. X., Chang, X., Xing, J., and Hao, J. M.: Modeling analysis of secondary inorganic aerosols over China: pollution characteristics, and meteorological and dust impacts, Sci. Rep., 6, 35992, https://doi.org/10.1038/srep35992, 2016.

Fu, X., Wang, T., Wang, S. X., Zhang, Lei, Cai, S. Y., Xing, J., and Hao, J. M.: Anthropogenic Emissions of Hydrogen Chloride and Fine Particulate Chloride in China, Environ. Sci. Technol., 52, 1644-1654, 2018.

Gebel, M. E. and Finlayson-Pitts, B. J.: Uptake and reaction of $\mathrm{ClONO}_{2}$ on $\mathrm{NaCl}$ and synthetic sea salt, J. Phys. Chem. A, 105, 5178-5187, 2001.

George, I. J. and Abbatt, J. P.: Heterogeneous oxidation of atmospheric aerosol particles by gas-phase radicals, Nat. Chem. 2, 713-722, 2010.

Glasow, V. R.: Wider role for airborne chlorine, Nature, 464, 168 169,2010

Goodman, A. L., Underwood, G. M., and Grassian, V. H.: Heterogeneous reaction of $\mathrm{NO}_{2}$ : characterization of gas-phase and adsorbed products from the reaction, $2 \mathrm{NO}_{2}(\mathrm{~g})+\mathrm{H}_{2} \mathrm{O}(\mathrm{a}) \rightarrow$ $\mathrm{HONO}(\mathrm{g})+\mathrm{HNO}_{3}$ (a) on Hydrated Silica Particles, J. Phys. Chem. A, 103, 7217-7223, 1999.

$\mathrm{Hu}$, J., Chen, J., Ying, Q., and Zhang, H.: One-year simulation of ozone and particulate matter in China using WRF/CMAQ modeling system, Atmos. Chem. Phys., 16, 10333-10350, https://doi.org/10.5194/acp-16-10333-2016, 2016.
Hu, J., Wang, P., Ying, Q., Zhang, H., Chen, J., Ge, X., Li, X., Jiang, J., Wang, S., Zhang, J., Zhao, Y., and Zhang, Y.: Modeling biogenic and anthropogenic secondary organic aerosol in China, Atmos. Chem. Phys., 17, 77-92, https://doi.org/10.5194/acp-1777-2017, 2017.

Jobson, B. T., Niki, H., Yokouchi, Y., Bottenheim, J. W., Hopper, F., and Leaitch, R. J.: Measurements of C2-C6 hydrocarbons during the Polar Sunrise 1992 experiment: Evidence for $\mathrm{Cl}$ atom and $\mathrm{Br}$ atom chemistry, J. Geophys. Res., 99, 25355-25368, 1994.

Keene, W. C., Pszenny, A. A. P., Jacob, D. J., Duce, R. A., Galloway, J. N., Schultz-Tokos, J. J., Sievering, H., and Boatman, J. F.: The Geochemical Cycling of Reactive Chlorine through the Marine Troposphere, Global Biogeochem., 4, 407-430, 1990.

Keene, W. C., Khalil, M. A. K., Erickson, D. J., McCulloch, A., Graedel, T. E., Lobert, J. M., Aucott, M. L., Gong, S. L., Harper, D. B., Kleiman, G., Midgley, P., Moore, R. M., Seuzaret, C., Sturges, W. T., Benkovitz, C. M., Koropalov, V., Barrie, L., and Li, Y. F.: Composite global emissions of reactive chlorine from anthropogenic and natural sources: Reactive Chlorine Emissions Inventory, J. Geophys. Res.-Atmos., 104, 8429-8440, 1999.

Kleeman, M. J., Ying, Q., and Kaduwela, A.: Control strategies for the reduction of airborne particulate nitrate in California's San Joaquin Valley, Atmos. Environ., 39, 5325-5341, 2005.

Knipping, E. M., Lakin, M. J., Foster, K. L., Jungwirth, P., Tobias, D. J., Gerber, R. B., Dabdub, D., and Finlayson-Pitts, B. J.: Experiments and simulations of ion-enhanced interfacial chemistry on aqueous $\mathrm{NaCl}$ aerosols, Science, 288, 301-306, 2000.

Li, H., Zhang, Q., Zheng, B., Chen, C., Wu, N., Guo, H., Zhang, Y., Zheng, Y., Li, X., and He, K.: Nitrate-driven urban haze pollution during summertime over the North China Plain, Atmos. Chem. Phys., 18, 5293-5306, https://doi.org/10.5194/acp18-5293-2018, 2018.

Li, Q., Zhang, L., Wang, T., Tham, Y. J., Ahmadov, R., Xue, L., Zhang, Q., and Zheng, J.: Impacts of heterogeneous uptake of dinitrogen pentoxide and chlorine activation on ozone and reactive nitrogen partitioning: improvement and application of the WRF-Chem model in southern China, Atmos. Chem. Phys., 16, 14875-14890, https://doi.org/10.5194/acp-16-148752016, 2016.

Liu, X. X., Qu, H., Huey, L. G., Wang, Y. W., Sjostedt, S., Zeng, L. M., Lu, K. D., Wu, Y. S., Hu, M., Shao, M., Zhu, T., and Zhang, Y. H.: High Levels of Daytime Molecular Chlorine and Nitryl Chloride at a Rural Site on the North China Plain, Environ. Sci. Technol., 51, 9588-9595, 2017.

Liu, Y., Fan, Q., Chen, X., Zhao, J., Ling, Z., Hong, Y., Li, W., Chen, X., Wang, M., and Wei, X.: Modeling the impact of chlorine emissions from coal combustion and prescribed waste incineration on tropospheric ozone formation in China, Atmos. Chem. Phys., 18, 2709-2724, https://doi.org/10.5194/acp-182709-2018, 2018.

Ma, X. Y., Sha, T., Wang, J. Y., Jia, H. L., and Tian, R.: Investigating impact of emission inventories on $\mathrm{PM}_{2.5}$ simulations over North China Plain by WRF-Chem, Atmos. Environ., 195, 125 140, 2018.

McDuffie, E. E., Fibiger, D. L., Dubé, W. P., Hilfiker, F., Lee, B. H., Thornton, J. A., Shah, V., Jaeglé, V., Guo, H. Y., Weber, R. J., Reeves, J. M., Weinheimer, A. J., Schroder, C. CampuzanoJost, P., Jimenez, J., Dibb, J. E., Veres, P., Ebben, C., Sparks, T. L., Wooldridge, P. J., Cohen, R. C., Hornbrook, R. S., Apel, E. 
C., Campos, T., Hall, S. R., Ullmann, K., and Brown, S. S.: Heterogeneous $\mathrm{N}_{2} \mathrm{O}_{5}$ uptake during winter: Aircraft measurements during the 2015 WINTER campaign and critical evaluation of current parameterizations, J. Geophys. Res.-Atmos., 123, 43454372, 2018a.

McDuffie, E. E., Fibiger, D. L., Dubé, W. P., Hilfiker, F., Lee, B. H., Thornton, J. A., Shah, V., Jaeglé, V., Guo, H. Y., Weber, R. J., Reeves, J. M., Weinheimer, A. J., Schroder, C. CampuzanoJost, P., Jimenez, J., Dibb, J. E., Veres, P., Ebben, C., Sparks, T. L., Wooldridge, P. J., Cohen, R. C., Hornbrook, R. S., Apel, E. C., Campos, T., Hall, S. R., Ullmann, K., and Brown, S. S.: $\mathrm{ClNO}_{2}$ yields from aircraft measurements during the $2015 \mathrm{WIN}$ TER campaign and critical evaluation of the current parameterization, J. Geophys.Res.-Atmos., 123, 12-994, 2018b.

Osthoff, H. D., Roberts, J. M., and Ravishankara, A. R.: High levels of nitryl chloride in the polluted subtropical marine boundary layer, Nat. Geosci., 1, 324-328, 2008.

Pratte, P. and Rossi, M. J.: The heterogeneous kinetics of $\mathrm{HOBr}$ and $\mathrm{HOCl}$ on acidified sea salt and model aerosol at 40-90\% relative humidity and ambient temperature, Phys. Chem. Chem. Phys., 8, 3988-4001, 2006.

Qiu, X. H., Chai, F. H., Duan, L., Chai, F. H., Wang, S. X., Yu, Q., and Wang, S. L.: Deriving High-Resolution Emission Inventory of Open Biomass Burning in China based on Satellite Observations, Environ. Sci. Technol., 50, 11779-11786, 2016.

Riedel, T. P., Bertram, T. H., Crisp, T. A., Williams, E. J., Lerner, B. M., Vlasenko, A., Li, S. M., Gilman, J., de Gouw, J., Bon, D. M., Wagner, N. L., Brown, S. S., and Thornton, J. A.: Nitryl Chloride and Molecular Chlorine in the Coastal Marine Boundary Layer, Environ Sci Technol., 46, 10463-10470, 2012.

Roberts, J. M., Osthoff, H. D., Brown, S. S., and Ravishankara, A. R.: $\mathrm{N}_{2} \mathrm{O}_{5}$ oxidizes chloride to $\mathrm{Cl}_{2}$ in acidic atmospheric aerosol, Science, 321, 1059-1059, 2008.

Rossi, M. J.: Heterogeneous Reactions on Salts, Chem. Rev., 103, 4823-4882, 2003.

Rudich, Y., Talukdar, R. K., Ravishankara, A. R., and Fox, R. W.: Reactive uptake of $\mathrm{NO}_{3}$ on pure water and ionic solutions, J. Geophys. Res., 101, 21023-21031, 1996.

Sarwar, G., Simon, H., Bhave, P., and Yarwood, G.: Examining the impact of heterogeneous nitryl chloride production on air quality across the United States, Atmos. Chem. Phys., 12, 6455-6473, https://doi.org/10.5194/acp-12-6455-2012, 2012.

Sarwar, G., Simon, H., and Xing, J: Importance of tropospheric $\mathrm{ClNO}_{2}$ chemistry across the Northern Hemisphere, Geophys. Res. Lett., 41, 4050-4058, 2014.

Seinfeld, J. H. and Pandis, S. N.: Atmospheric Chemistry and Physics: From Air Pollution to Climate Change, WileyInterscience, New York, USA, 2006.

Spicer, C. W., Chapman, E. G., Finlayson-Pitts, B. J., Plastridge, R. A., Hubbe, J. M., Fast, J. D., and Berkowitz, C. M.: Unexpectedly high concentrations of molecular chlorine in coastal air, Nature, 394, 353-356, 1998.

Tham, Y. J., Wang, Z., Li, Q., Wang, W., Wang, X., Lu, K., Ma, N., Yan, C., Kecorius, S., Wiedensohler, A., Zhang, Y., and Wang, T.: Heterogeneous $\mathrm{N}_{2} \mathrm{O}_{5}$ uptake coefficient and production yield of $\mathrm{ClNO}_{2}$ in polluted northern China: roles of aerosol water content and chemical composition, Atmos. Chem. Phys., 18, 1315513171, https://doi.org/10.5194/acp-18-13155-2018, 2018.
Thornton, J. A., Kercher, J. P., Riedel, T. P., Wagner, N. L., Cozic, J., Holloway, J. S., Dubé, W. P., Wolfe, G. M., Quinn, P. K., Middlebrook, A. M., Alexander, B., and Brown, S. S.: A large atomic chlorine source inferred from mid-continental reactive nitrogen chemistry, Nature, 464, 271-274, 2010.

Tuazon, E. C., Atkinson, R., Plum, C. N., Winer, A. M., and Pitts Jr., J. N.: The reaction of gas phase $\mathrm{N}_{2} \mathrm{O}_{5}$ with water vapor, Geophys. Res. Lett., 10, 953-956, 1983.

Wang, H. C., Lu, K. D., Chen, X. R., Guo. S., Jiang, M. Q., Li, X., Shang, D. J., Tian, Z. F., Wu, Y. S., Wu, Z. J., Zou, Q., Zheng, Y., Zeng, L. M., Zhu, T. Hu, M., and Zhang, Y. H.: High $\mathrm{N}_{2} \mathrm{O}_{5}$ concentrations observed in urban Beijing: implications of a large nitrate formation pathway, Environ. Sci. Technol. Lett., 4, 416420, 2017.

Wang, S. X., Zhao, B., Cai, S. Y., Klimont, Z., Nielsen, C. P., Morikawa, T., Woo, J. H., Kim, Y., Fu, X., Xu, J. Y., Hao, J. M., and He, K. B.: Emission trends and mitigation options for air pollutants in East Asia, Atmos. Chem. Phys., 14, 6571-6603, https://doi.org/10.5194/acp-14-6571-2014, 2014.

Wen, L., Xue, L., Wang, X., Xu, C., Chen, T., Yang, L., Wang, T., Zhang, Q., and Wang, W.: Summertime fine particulate nitrate pollution in the North China Plain: increasing trends, formation mechanisms and implications for control policy, Atmos. Chem. Phys., 18, 11261-11275, https://doi.org/10.5194/acp-18-112612018, 2018.

Wu, X. W., Chen, W. W., Wang, K., Xiu, A. J., Zhang, S. C., Zhao, H. M., and Zhang, X. L.: $\mathrm{PM}_{2.5}$ and VOCs emission inventories from cooking in Changchun city, China Environmental Science, 38, 2882-2889, 2018.

Ying, Q., Li, J. Y., and Kota, S. H.: Significant Contributions of Isoprene to Summertime Secondary Organic Aerosol in Eastern United States, Environ. Sci. Technol., 49, 7834-7842, 2015.

Young, C. J., Washenfelder, R. A., Edwards, P. M., Parrish, D. D., Gilman, J. B., Kuster, W. C., Mielke, L. H., Osthoff, H. D., Tsai, C., Pikelnaya, O., Stutz, J., Veres, P. R., Roberts, J. M., Griffith, S., Dusanter, S., Stevens, P. S., Flynn, J., Grossberg, N., Lefer, B., Holloway, J. S., Peischl, J., Ryerson, T. B., Atlas, E. L., Blake, D. R., and Brown, S. S.: Chlorine as a primary radical: evaluation of methods to understand its role in initiation of oxidative cycles, Atmos. Chem. Phys., 14, 3427-3440, https://doi.org/10.5194/acp-14-3427-2014, 2014.

Zhang, T., Peng, L., and Li, Y. H.: Chemical characteristics of $\mathrm{PM}_{2.5}$ emitted from cooking fumes, Res. Environ. Sci., 29, 183191, 2016 (in Chinese).

Zhou, W., Zhao, J., Ouyang, B., Mehra, A., Xu, W., Wang, Y., Bannan, T. J., Worrall, S. D., Priestley, M., Bacak, A., Chen, Q., Xie, C., Wang, Q., Wang, J., Du, W., Zhang, Y., Ge, X., Ye, P., Lee, J. D., Fu, P., Wang, Z., Worsnop, D., Jones, R., Percival, C. J., Coe, H., and Sun, Y.: Production of $\mathrm{N}_{2} \mathrm{O}_{5}$ and $\mathrm{ClNO}_{2}$ in summer in urban Beijing, China, Atmos. Chem. Phys., 18, 11581-11597, https://doi.org/10.5194/acp-18-11581-2018, 2018. 